\title{
Competition in sympatric white-tailed deer and cattle populations in southern pine forests of Oklahoma and Arkansas, USA
}

\author{
Jonathan A. JENKS*, David M. LESLIE Jr, Robert L. LOCHMILLER, \\ M. Anthony MELCHIORS and Foris T. McCOLLUM III
}

Jenks J. A., Leslie D. M. Jr, Lochmiller R. L., Melchiors M. A. and McCollum F. T. III. 1996. Competition in sympatric white-tailed deer and cattle populations in southern pine forests of Oklahoma and Arkansas, USA. Acta Theriologica 41: 287-306.

Inferences on competitive interactions between white-tailed deer Odocoileus virginianus (Zimmermann, 1780) and cattle were made using information on diet composition and quality. We hypothesized that dietary overlap between deer and cattle would increase with cattle density and that quality of deer diets would be higher in areas not exposed to cattle than in areas that were stocked with moderate to high cattle densities. Three treatments were delineated in McCurtain County, Oklahoma (heavy cattle stocking), and Howard (moderate to light cattle stocking) and Pike (no cattle stocking) counties, Arkansas. Treatments were similar with respect to soils and vegetation but differed with respect to cattle stocking rate (ie number of cattle/ha). Deer and cattle diets and concentrations of fecal nitrogen (FN) (an index to dietary quality) were determined from feces that were obtained from 12 randomly selected collection areas (4/treatment) from October 1986 to October 1988. Dietary overlap of deer and cattle was highest in winter and lowest in summer. Dietary overlap of deer populations was lowest for populations exposed to heavy cattle stocking and no cattle stocking, which suggested that competition between the deer and cattle occurred in winter. Fecal nitrogen was lowest in deer feces collected from treatments with cattle stocking in February but higher in August and October. Both dietary quality and dietary overlap suggested possible competitive interactions between deer and cattle in winter. However, higher dietary forb and dietary quality for deer in summer exposed to cattle suggested that cattle can facilitate growth of early successional plant species in pine habitats.

Oklahoma Cooperative Fish and Wildlife Research Unit, Department of Zoology, Oklahoma State University, Stillwater, Oklahoma 74078, USA (JAJ); United States National Biological Service, Oklahoma Cooperative Fish and Wildlife Research Unit, Department of Zoology, Oklahoma State University, Stillwater, Oklahoma 74078, USA (DML); Department of Zoology, Oklahoma State University, Stillwater, Oklahoma 74078, USA (RLL); Weyerhaeuser Company, Box 1060, Hot Springs, Arkansas 71902, USA (MAM); Department of Animal Science, Oklahoma State University, Stillwater, Oklahoma 74078, USA (FTM)

Key words: Odocoileus virginianus, cattle, competition, diet composition, diet quality, fecal nitrogen, white-tailed deer *Present address: Department of Wildlife and Fisheries Sciences, South Dakota State University, Box
2140 B, Brookings, SD 57007-1696, USA. To whom reprint request should be sent. 


\section{Introduction}

The nature and extent of competitive interactions between sympatric ungulates ultimately determine the dynamics of their populations (Leslie et al. 1984, Gordon 1988, Jenkins and Wright 1988). Competition causes negative effects on one or all sympatric ungulate species and can result in reduced numbers, animal performance, or forage availability. Conversely, facilitative effects by one or more species can improve forage conditions, which results in increased diversity of ungulate species (Bell 1971, Sinclair 1979). Relative to white-tailed deer, cattle are considered minor competitors because of significant differences in gastrointestinal morphology that enable deer to subsist on browse (ie concentrates) (Hofmann 1988). Nevertheless, evidence indicates that under high stocking regimes, cattle may be better competitors for available forage and cause deer to forage in areas that contain vegetation of lower nutritional value (Crawford 1984).

Significant dietary overlap between cattle and deer could occur in the loblolly pine Pinus taeda/short-leaf pine $P$. echinata/hardwood forest type that occurs in Qklahoma and Arkansas because of heavy cattle stocking found in some oak Quercus spp.-pine forests and regenerating pine plantations. As such, presence of cattle also could affect dietary quality of deer. Because deer forage extensively on mast in winter (Korschgen 1962, Harlow et al. 1975), low mast production could promote competition between deer and cattle for available browse species, which are low in nutrients in winter (Fuller 1976). In addition to possible competitive interactions, cattle might facilitate vegetation composition for deer (ie enhance forb growth) when foraging indiscriminantly (Welch and Hooper 1988) in pine plantations.

The purpose of our study was to assess competitive interactions between white-tailed deer Odocoileus virginianus (Zimmermann, 1780) and cattle by comparing seasonal differences in dietary characteristics and quality of collected fecal samples. We hypothesized that dietary overlap between deer and cattle would increase with cattle density and that quality of deer diets would be higher in an area not exposed to cattle than in areas that were stocked with moderate to high cattle densities.

\section{Methods}

\section{Experimental area}

Southeastern Oklahoma and southwestern Arkansas together comprise the Athens Piedmont Plateau, which is considered a subdivision of the Ouachita Mountains of Oklahoma and krkansas, USA (Foti 1974). The area is diverse vegetationally and is surrounded by vegetational conmunities (ie eastern forested region of Arkansas, midwestern prairie region of Oklahoma, and coastal region of eastern Texas) that supplant southern pine forest. Elevation of the plateau ranges from abcut 128 to $321 \mathrm{~m}$ above mean sea level (Foti 1974). Climate is subtropical with hot, humid summers and mild winters; rainfall averages $1372 \mathrm{~mm} /$ year (Fuller 1976). Plateau soils are of 3 associations; Redland, 
Kiamichi, and Chula (Jenkins and Steinbrenner 1981, James 1982). Redland soils occur predominantly in areas of relatively level topography, but Kiamichi and Chula soils characterize slopes of $20-65 \%$. Dominant tree species of the plateau are white oak Quercus alba, loblolly pine, and shortleaf pine; however, tracts ( $\leq 300 \mathrm{ha}$ ) of forest have been commercially harvested and replanted with loblolly pine seedlings.

Weyerhaeuser Company - a private forest products corporation - has owned about 728000 ha of land (about 353000 ha in Oklahoma and 375000 ha in Arkansas) on and surrounding the Athens Piedmont Plateau since 1969 and harvests natural second-growth forest (ie shortleaf pine and mixed hardwoods) and commercially planted tracts of loblolly pine. As of 1983, about 235 permittees were licensed to graze 15000 head of cattle per year on Weyerhaeuser lands in Oklahoma (Unpubl. Rep., Weyerhaeuser Company, Hot Springs, Arkansas, USA).

Three treatments were selected within an area of variable cattle stocking regimes. Treatments were similar in geographical and overstory vegetational characteristics and were located in McCurtain County, Oklahoma USA ( $34^{\circ} 15^{\prime}$ to $34^{\circ} 25^{\prime} \mathrm{N}, 94^{\circ} 45^{\prime}$ to $94^{\prime \prime} 50^{\prime} \mathrm{W}$ ) (heavy cattle stocking); Howard County, Arkansas USA ( $34^{\circ} 10^{\prime}$ to $34^{\circ} 20^{\prime} \mathrm{N}, 94^{\circ} 5^{\prime}$ to $94^{\prime} 15^{\prime} \mathrm{W}$ ) (moderate to light cattle stocking); and Pike County, Arkansas USA ( $34^{\circ} 15^{\prime}$ to $34^{\circ} 20^{\prime} \mathrm{N}, 93^{\circ} 40^{\prime}$ to $93^{\circ} 50^{\prime} \mathrm{W}$ ) (no cattle stocking) (Fig. 1). Pike County served as a control in our study design. Since 1982, licensed cattle stocking levels were 839 animal units (AU) on 9612 ha (11.4 ha/AU) and $188 \mathrm{AU}$ on $9349 \mathrm{ha} \mathrm{(49.8} \mathrm{ha/AU)} \mathrm{in} \mathrm{McCurtain} \mathrm{and} \mathrm{Howard}$ counties, respectively. However, observation rates of cattle (including calves) from helicopter surveys of young pine plantations were $1 \mathrm{cow} / 3$ ha and $1 \mathrm{cow} / 15$ ha for McCurtain and Howard counties, respectively (Unpubl. Rep., Weyerhaeuser Co., Hot Springs, Ark). Cattle were stocked seasonally (April to October) in Howard County in 1987 but year-round in 1988 (due to the presence of trespass cattle).

Four disjunct areas for fecal collections were selected randomly in each of the 3 treatments. Average size of collection areas was 1241 ha $(\mathrm{SE}=76 \mathrm{ha}$ ) across the 3 treatments (McCurtain: 1292 \pm 148 ha; Howard: $1346 \pm 77$ ha; Pike: $1087 \pm 152$ ha). Similar percentages of overstory habitat features were considered necessary to ensure proper juxtaposition and interspersion of habitats

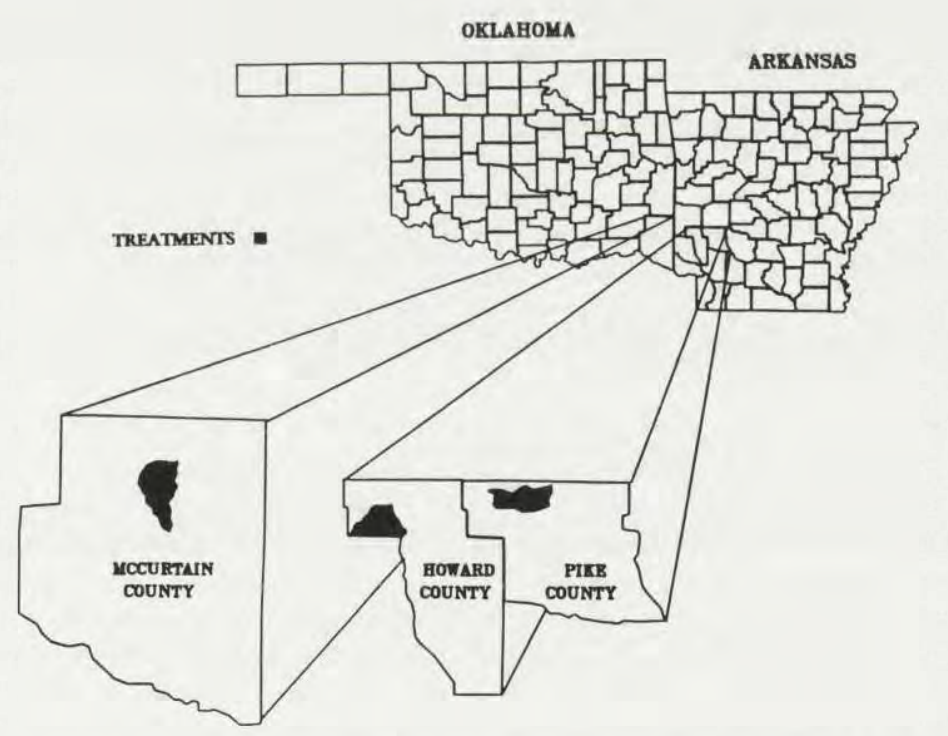

Fig. 1. Locations of the three treatments in McCurtain (Oklahoma), Howard and Pike (Arkansas) counties, USA. 
within collection areas. Collection areas contained similar amounts of natural oak/pine habitat, loblolly pine plantations that were planted $\geq 5$ years prior to the study, and loblolly pine plantations that were planted $<5$ years prior to the study or would be planted within the first year of the study. Other characteristics (eg plantation age) varied among collection areas within treatments. Collection areas were at least $1.6 \mathrm{~km}$ apart from one another, and given that the area of deer home ranges in McCurtain County averaged 40 ha (Nelson 1981), minimal overlap likely occurred in deer use of collection areas. Thus, collection areas were considered independent treatment replicates in statistical analyses.

\section{Dietary analyses}

Plant material (leaves, stems, fruit) was collected to use as comparative reference material for identification of plant fragments in deer and cattle feces. Plant material was dried in a plant press, identified to species, and a subsample was prepared for microscopic characterization using the procedures outlined by Davitt and Nelson (1980).

Fresh fecal samples (Jenks et al. 1990) of deer and cattle were collected seasonally lie fall (Oct), winter (Feb), spring (May), summer (Aug)] from all collection areas from October 1986 to October 1988. Random transects were established in pine plantations and natural vegetation containing evidence of deer. We surveyed transects on foot and attempted to collect a minimum of 15 deer fecal samples (Anthony and Smith 1974) in each collection area; 25 and 10 fecal samples of cattle were collected in McCurtain and Howard counties, respectively. Fecal samples were individually dried and composited for each collection area across seasons (Jenks et al. 1989). Subsamples (ie 1-g aliquots) of composited feces were prepared for analysis of dietary composition (Davitt and Nelson 1980).

Botanical composition of composited fecal samples was determined by randomly (Whysong and Miller 1987) locating 100 microscope fields on 4 slides (25 fields/slide) (Sparks and Malechek 1968), identifying plant fragments within the field at $100-400 \times$ by comparing fecal plant fragments with specimens in the reference collection (Holechek and Valdez 1985), and counting the number of square microns (at 100x) of each plant fragment [ie fragment area (Stewart 1967)]. Fragment identification was conducted by only one person (JAJ) to reduce error that has been reported for similar dietary analyses (Alipayo et al. 1992). Percent composition of each plant species was calculated by summing the total number of square microns per plant species and dividing by the total number of square microns counted per composited sample. Percent composition of individual plant species consumed by cattle and deer was summed by forage class (ie browse, conifer, fern, forb, grass, mast, and other) to compare deer and cattle populations. Conifers were separated from browse because their nutritional characteristics (digestibility, secondary compounds) differ markedly from those of deciduous trees and shrubs (Blair et al. 1977). Dietary overlap was calculated from percentages of individual plant species (Jenks 1991) using the procedure outlined by Anthony and Smith (1977).

As an index of dietary quality (Leslie and Starkey 1985, 1987), we used the Kjeldahl method (Williams 1984) to determine nitrogen levels in fecal samples. Sample preparation was as described by Jenks et al. (1989).

\section{Statistical analyses}

To correct for problems associated with percentages, dietary percentages were arcsine transformed after performing a square root transformation (Sokal and Rohlf 1981: 427). Initially, dietary information was compared by category (eg conifer) and species (deer vs cattle) using ANOVA to assess overall variation in diets. Diet categories were compared within ungulate species by treatment and season and the interaction between treatment and season using ANOVA. All data were combined for the 2 years of the study to reduce the chance of a Type I error (Sokal and Rohlf 1981 159) [ie combined data increased seasonal variation, which decreased the chance that differences in diet categories would be found when no difference among treatment, season, or species occurred (W. D. Warde, Department of Statistics, Oklahoma State University; pers. comm.)]. 
A multivariate statistical approach was used to test hypotheses concerning competitive interactions among deer and cattle populations. A principal component analysis with varimax rotation of factors (Johnson and Wichern 1988: 403) was conducted on dietary percentages of browse, grass, fern, forb, mast, and conifer for cattle and deer combined. MANOVA was used to evaluate differences in principal components scores (by treatment, season and species). A priori hypothesis testing was used in all analyses to ascertain if (1) deer under no cattle stocking differed from deer under cattle stocking and (2) deer under moderate stocking differed from deer under heavy stocking. Bartlett's tests (Sokal and Rohlf 1981: 403) were used to test for heteroscedasticity in FN; if variances were heterogeneous, data were rank transformed (Conover and Iman 1981) before comparing deer and cattle relative to treatments. Comparisons of FN for treatments and seasons were conducted using $t$-tests or ANOVA.

\section{Results}

\section{Dietary analyses}

Deer diets

Richness of deer diets was high during all seasons studied (Jenks 1991). Browse (eg honeysuckle Lonicera spp./coralberry Symphoricarpos orbiculatus, dogwood Cornus spp., oak Quercus spp.), including conifers (eg Pinus spp. and red-cedar Juniperus virginiana), was the major constituent in deer diets in all seasons (Fig. 2). Conifers were highest in February diets in all 3 treatments and increased from $11 \%$ and $6 \%$ to $49 \%$ and $27 \%$ from February 1987 to 1988 in McCurtain and Howard counties, respectively.

Forbs constituted $48 \%$ and $46 \%$ of deer diets in Howard County in May 1987 and McCurtain County in May 1988, respectively (Fig. 2). Major forbs in deer diets included pussytoes Antennaria plantaginifolia, mallow Abutilon threophrasti, Lespedeza spp., Solidago spp., and woolly croton Croton capitatus (Jenks 1991). Pike County diets were consistently lowest in forbs in both winters $(5 \%$ and $3 \%$ for February 1987-1988). Mast (eg acorns, Rhus spp. seed heads, Prunus spp. drupes) in deer diets varied from a high of $31 \%$ of diets of Pike County deer in August 1988 to a low of $1 \%$ of diets of McCurtain County deer in May 1987. Ferns (eg Christmas fern Polystichum acrosticoides) accounted for $14 \%$ and $17 \%$ of deer diets in February 1987 in McCurtain County and in February 1988 in Howard County, respectively (Fig. 2). Grass (eg Panicum spp.) composition of deer diets was highest in February and May diets and ranged from $17 \%$ to a low of $0.3 \%$ in Howard County in February 1988 and August 1987, respectively.

Winter deer diets tended to be composed of the fewest plant species (Jenks 1991) and depending on treatment, diets were dominated by conifers or Caprifoliaceae (ie honeysuckle/coralberry). Dietary conifer was negatively related to dietary Caprifoliaceae in winter in $\operatorname{deer}(F=12.526, \mathrm{df}=1,22, p=0.002)$. Diets of Pike County deer were generally high in Caprifoliaceae and low in conifer in winter, whereas diets of McCurtain County deer were generally high in conifer and low in Caprifoliaceae. Diets of Howard County deer were intermediate with respect to both dietary categories. 


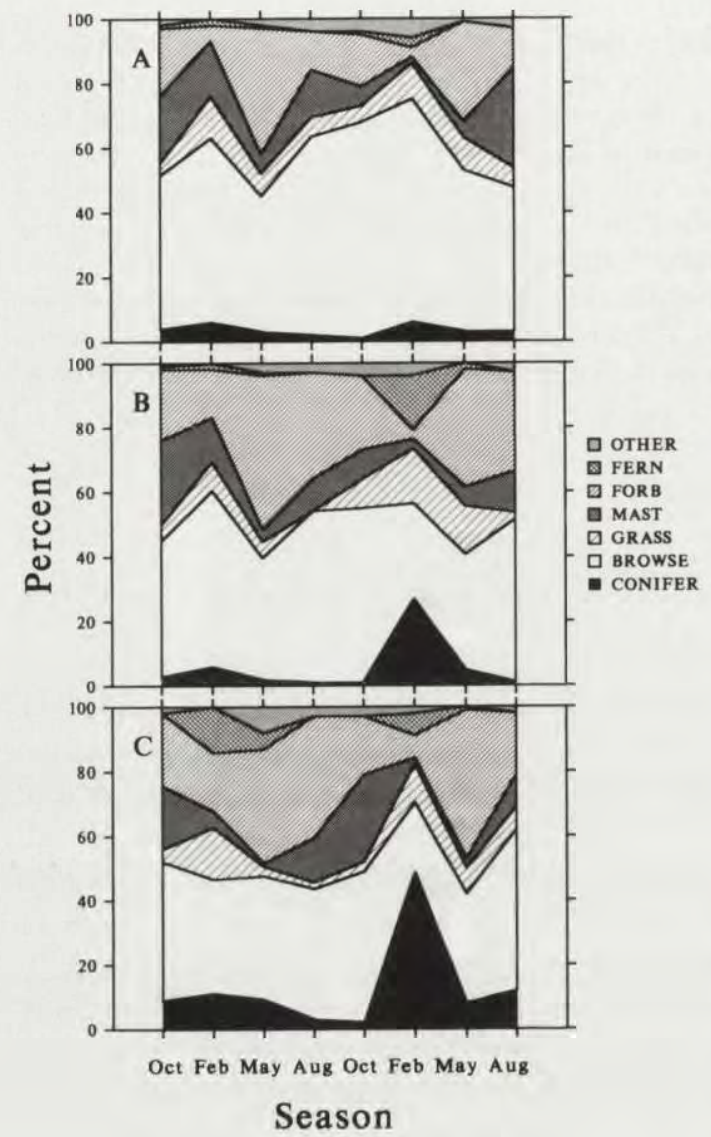

Fig. 2. Seasonal diets of white-tailed deer by primary forage class determined from microhistological analysis of fecal samples collected in treatments in Pike (A) and Howard (B) counties (Arkansas) and McCurtain (C) County (Oklahoma), October 1986 to August 1988.

\section{Cattle diets}

Percentages of grasses in cattle diets ranged from a low of $59 \%$ in McCurtain County in October 1987 to a high of $96 \%$ in Howard County in August 1987 (Fig. 3). Browse and conifer occurred in smaller proportions in cattle diets in Howard County than in McCurtain County throughout our study. Use of browse and conifer by cattle peaked in February in both years and corresponded with peak use of conifers by deer in McCurtain and Howard counties (Fig. 2).

Although mast and ferns accounted for a significant proportion of deer diets, they were not abundant in cattle diets in either McCurtain or Howard counties (Fig. 3). Use of forbs by cattle varied seasonally and ranged from a high of $26 \%$ in October 1987 in McCurtain County to a low of 3\% in Howard County in February 1988. Use of forbs (eg Lespedeza spp., woolly croton, Solidago spp.) by cattle, as with browse and conifer, tended to be lower in Howard County (except during May 1987) than McCurtain County. 
Fig. 3. Seasonal diets of cattle by primary forage class determined from microhistological analysis of fecal samples collected in Howard (A) County (Arkansas) and McCurtain (B) County (Oklahoma), October 1986 to August 1988.

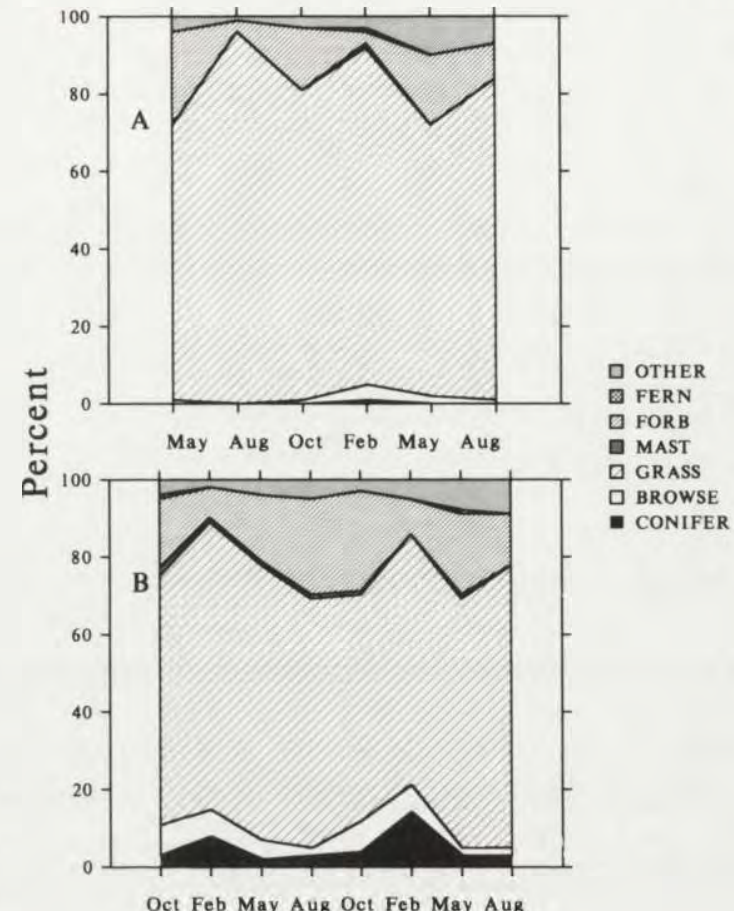

Season

\section{Diet overlap}

Similarity indices calculated from dietary proportions of plant species ranged from 2.5 to $66.8 \%$ across all possible within and between species comparisons (Table 1). Generally, deer diets were more similar to deer diets from other treatments than to cattle diets. Dietary overlap between populations of deer from McCurtain and Pike counties tended to be lower than either McCurtain-Howard or Howard-Pike comparisons, despite the high dietary overlap that occurred in October 1986 (Table 1). Low dietary overlap indicated that deer diets from the heavily stocked treatment were most dissimilar from deer on the treatment without cattle. Dietary overlap between sympatric deer and cattle populations was relatively low $(<35 \%)$ but tended to be higher in McCurtain County than Howard County.

\section{Comparisons of diet composition}

A total of 152 (96 deer, 56 cattle) composited fecal samples was analyzed. When dietary percentages for deer and cattle were compared over all seasons and years, browse $(F=613.59, \mathrm{df}=1,150, p<0.001)$, conifer $(F=11.69, \mathrm{df}=1,150, p=0.001)$, fern $(F=16.14$, df $=1,150, p<0.001)$, forb $(F=10.05$, df $=1,150, p=0.002)$, grass $(F=1159.79, \mathrm{df}=1,150, p<0.001)$, and mast $(F=110.76, \mathrm{df}=1,150$, 
Table 1. Percent dietary overlap (as described by Anthony and Smith 1977) by season of collection for white-tailed deer and cattle in heavy, moderate, and no cattle stocking treatments located in McCurtain County (Oklahoma), and Howard and Pike counties (Arkansas), respectively.

\begin{tabular}{lccccc}
\hline Season & $\begin{array}{c}\text { McCurtain-Howard } \\
\text { (deer) }\end{array}$ & $\begin{array}{c}\text { McCurtain-Pike } \\
\text { (deer) }\end{array}$ & $\begin{array}{c}\text { Howard-Pike } \\
\text { (deer) }\end{array}$ & $\begin{array}{c}\text { McCurtain } \\
\text { (deer-cattle) }\end{array}$ & $\begin{array}{c}\text { Howard } \\
\text { (deer-cattle) }\end{array}$ \\
\hline October 1986 & 61.6 & 64.3 & 64.4 & 21.8 & - \\
February 1987 & 54.8 & 38.9 & 47.9 & 31.2 & - \\
May 1987 & 57.4 & 59.0 & 62.7 & 20.7 & 14.3 \\
August 1987 & 66.8 & 40.2 & 52.7 & 16.7 & 2.5 \\
October 1987 & 57.0 & 43.9 & 60.4 & 14.0 & 16.4 \\
February 1988 & 61.7 & 34.2 & 43.2 & 34.6 & 20.1 \\
May 1988 & 62.0 & 59.0 & 66.0 & 21.5 & 22.1 \\
August 1988 & 62.2 & 43.5 & 41.7 & 17.6 & 8.4 \\
\hline
\end{tabular}

$p<0.001)$ forage classes differed significantly. Percentages of browse, conifer fern, forb, and mast were higher in deer diets, and percent grass was higher in cattle diets.

Within deer populations, data were analyzed by treatment and season with years combined. Percent dietary browse differed $(F=22.61, \mathrm{df}=1,84, p<0.001)$ among populations with higher levels in diets of deer in Pike County than in McCurtain and Howard counties. Dietary conifer also differed among dear populations; deer diets were lower $(F=11.40, \mathrm{df}=1,84, p=0.001)$ in conifer in Pike County than McCurtain and Howard counties. Furthermore, conifer levels were higher $(F=15.66, \mathrm{df}=1,84, p<0.001)$ in McCurtain than Howard County deer diets. No difference $(F=0.28, \mathrm{df}=2,84, p=0.76)$ in dietary grass was found among deer populations. A significant $(F=2.36, \mathrm{df}=6,84, p=0.04)$ treatment by season interaction was found for percent dietary mast. Percent mast in deer diets was higher $(F=9.21, \mathrm{df}=1,21, p=0.006)$ in Howard County than McCurtain County in May, but percent mast in deer diets was higher $(F=9.07, \mathrm{df}=1,21$, $p=0.007)$ in Pike County than McCurtain and Howard counties in Auzust. No differences in dietary mast occurred among deer populations in October $(\vec{f}=2.02$, $\mathrm{df}=2,21, p=0.16)$ or February $(F=0.67, \mathrm{df}=2,21, p=0.52)$. Percertages of forbs in deer diets also differed among populations; levels in deer diets rom the Pike County treatment were lower $(F=17.12, \mathrm{df}=1,84, p<0.001)$ than other treatments. Ferns in deer diets did not differ $(F=1.74, \mathrm{df}=2,84, p=0.1 \varepsilon)$ among treatments.

Composition of cattle diets also differed among treatments. Browse $(F=30.63$, $\mathrm{df}=1,48, p<0.001)$, conifer $(F=47.88, \mathrm{df}=1,48, p<0.001)$, and mast $(\bar{I}=5.27$, $\mathrm{df}=1,48, p=0.03$ ) percentages in cattle diets were lower in Howard Couty than McCurtain County. Treatment by season interactions were found for both grasses $(F=5.94, \mathrm{df}=3,48, p=0.002)$ and forbs $(F=4.97, \mathrm{df}=3,48, p=0.004)$. Percent dietary grass was higher for cattle in Howard County in October $(F=23.47$, 
$\mathrm{df}=1,10, p=0.001)$, February $(F=9.96, \mathrm{df}=1,10, p=0.01)$, and August $(F=27.11, \mathrm{df}=1,14, p<0.001)$ but not in May $(F=0.57, \mathrm{df}=1,14, p=0.46)$. Conversely, percent dietary forb was greater for cattle in McCurtain County than Howard County in February $(F=9.19, \mathrm{df}=1,10, p=0.01)$ and August $(F=15.92$, $\mathrm{df}=1,14, p=0.001)$ but not in October $(F=1.24, \mathrm{df}=1,10, p=0.29)$ or May $(F=0.52, \mathrm{df}=1,14, p=0.48)$. No difference $(F=0.05, \mathrm{df}=1,48, p=0.829)$ in percentage of fern was found for cattle diets from McCurtain and Howard counties. Because fern was rarely found in cattle diets, no further analyses were conducted on this forage category.

A total of $91.5 \%$ of the variation in conifer, browse, forb, grass, and mast forage categories was explained by the first 3 principal components. The first principal component was a linear combination of forage categories with dietary browse, mast, and grass contributing largely to component scores [ie $Y_{1}=0.91$ (browse) 0.89 (grass) +0.87 (mast) +0.06 (conifer) +0.11 (forb) $]$. Principal component 2 [ie $Y_{2}$ $=-0.13$ (browse $)+0.22$ (grass) +0.16 (mast) -0.98 (conifer $)+0.14$ (forb) $]$ and principal component 3 [ie $Y_{3}=-0.09$ (browse) +0.35 (grass) +0.05 (mast) + 0.13 (conifer) -0.98 (forb)] were linear combinations of forage categories with dietary conifer and forb contributing the greatest to component scores, respectively. Thus, synthetic components (ie principal component scores) formed axes of browse and mast versus grass, conifer, and forb.

Principal component scores were compared across treatments and ungulate species using MANOVA. Separate MANOVAs were calculated by season because of an interaction of treatment with season (deer: $F=1.76, \mathrm{df}=18,232, p=0.031$; cattle: $F=2.83, \mathrm{df}=9,112, p=0.005$ ). In October, deer and cattle diets differed significantly $(F=183.34, \mathrm{df}=3,32, p<0.001)$ with predominant separation occurring on principal component 1 (ie browse and mast versus grass component) (Fig. 4A). Separation between deer and cattle also occurred on both forb (PC-3) and conifer (PC-2) axes. No differences occurred in synthetic dietary factors among deer populations in October $(F=0.36, \mathrm{df}=3,19, p=0.784)$. However, component scores for cattle populations differed significantly $(F=56.24 \mathrm{df}=3,8, p<0.001)$ with predominant separation occurring on the first and second principal components.

In February, deer and cattle differed across dietary principal components $(F=53.13, \mathrm{df}=3,32, p<0.001$ ) (Fig. 4B). As in October, predominant separation occurred along principal component 1 . Separation $(F=7.66, \mathrm{df}=3,19, p=0.001)$ also occurred among deer populations; deer in Pike County differed from those in McCurtain and Howard counties. Separation occurred on all 3 axes with deer from treatments exposed to cattle stocking consuming more forbs and conifers and less browse and mast compared to the treatment without cattle (ie Pike County). Differences $(F=4.73, \mathrm{df}=3,8, p=0.035)$ also occurred between the 2 cattle populations with predominant separation occurring on the second and third (ie conifer and forb, respectively) principal components.

In May, separation between deer and cattle dietary factors occurred on all 3 principal components $(F=340.31, \mathrm{df}=3,36, p<0.001)$ (Fig. $4 \mathrm{C})$. Although no 
differences were found among the 3 deer populations $(F=2.17, \mathrm{df}=3,19, p=0.125$ ), dietary factors of cattle populations differed $(F=5.07, \mathrm{df}=3,12, p=0.017)$ with predominant separation occurring on first and second principal components.

In August, deer and cattle differed across synthetic dietary factors with primary separation occurring on principal component $1(F=262.57, \mathrm{df}=3,36, p<0.001)$ (Fig. 4D). Synthetic scores for deer populations differed $(F=13.95$, df $=3,19$, $p<0.001$ ); component scores for deer in Pike County differed from McCurtain and Howard. Predominant separation occurred on first and third principal components with deer from treatments with cattle consuming more forbs and less browse and mast than deer from Pike County. Cattle populations also differed $(F=17.04$,
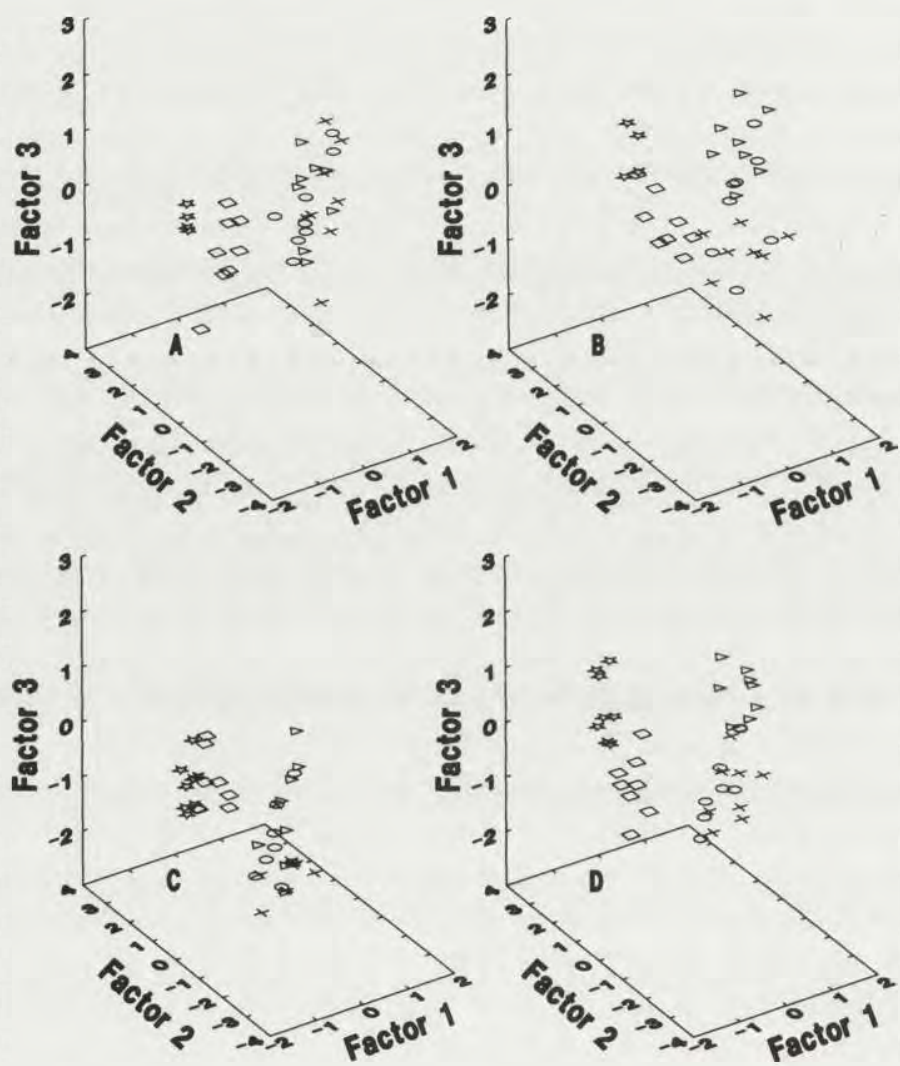

Fig. 4. Principal component scores by season of collection derived from forage class percentages of feces collected from treatments (heavy, moderate, and no cattle stocking) in Oklahoma and Arkansas (USA) from wild ranging white-tailed deer and cattle. Dietary percentages were determined from microhistological analysis of white-tailed deer and cattle fecal samples collected in McCurtain County (Oklahoma), and Howard and Pike counties (Arkansas), October 1986 to August 1988. Seasons of collection were October (A), February (B), May (C), and August (D). Symbols refer to ungulate species and treatments: crosses - McCurtain deer, ovals - Howard deer, triangles - Pike deer, squares McCurtain cattle, stars - Howard cattle. 
$\mathrm{df}=3,12, p<0.001)$ in August with primary separation occurring on all 3 principal components.

\section{Dietary quality}

Mean concentration of FN ranged from a low of $1.17 \%$ for cattle from Howard County in February 1988 to a high of $3.29 \%$ for deer from Howard County in May 1987. Analysis of FN levels of deer was conducted on data collected from February 1987 to October 1988 because cattle feces were not collected in October 1986. Furthermore, comparisons of cattle populations could only be conducted for 2 seasons (ie May and August) with ANOVA because fecal samples of cattle from Howard County were not available in some seasons. Cattle feces were collected in McCurtain and Howard counties in October 1987 and February 1988; $t$-tests were used to compared FN for these 2 seasons.

A strong seasonal effect was apparent in concentrations of FN in deer and cattle feces (Fig. 5). Lowest levels occurred in February and peak levels occurred in May, but a treatment by season interaction $(F=4.36, \mathrm{df}=6,84, p=0.001)$ was observed for deer. Thus, FN of deer was analyzed seasonally when assessing differences among treatments. Concentration of FN in deer feces from Pike County

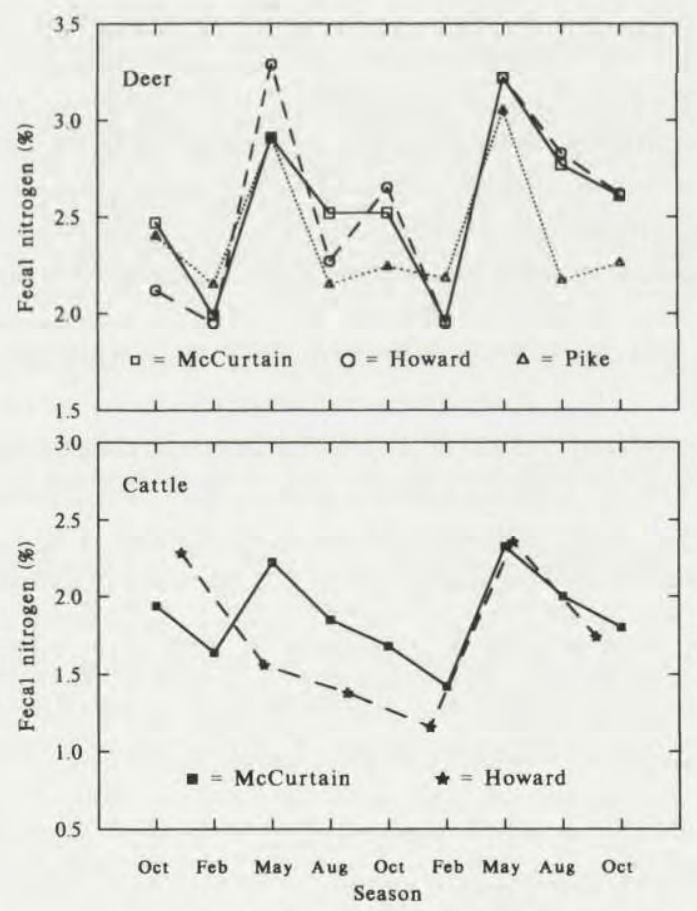

Fig. 5. Concentration of fecal nitrogen $(\%)$ of white-tailed deer and cattle by treatment determined from composited fecal samples collected in McCurtain County (Oklahoma) and Howard and Pike counties (Arkansas), October 1986 to October 1988. 
was lower than McCurtain and Howard counties in August $(F=12.09, \mathrm{df}=1,21$, $p=0.002)$ and October $(F=7.71, \mathrm{df}=1,21, p=0.01)$, but higher in February $(F=12.54, \mathrm{df}=1,21, p=0.002)$. No differences $(F=0.79, \mathrm{df}=2,21, p=0.47)$ in FN of deer occurred across treatments in May.

Concentration of FN for cattle varied seasonally from a low in February to a peak in May (Fig. 5), but an treatment by season interaction $(F=15.24$, df $=1,28$, $p=0.001$ ) also was evident. Levels of FN were lower in cattle from Howard County than McCurtain County in August $(F=18.97, \mathrm{df}=1,14, p=0.001$ ), October 1987 $(t=8.71, \mathrm{df}=6, p<0.001)$ and February $1988(t=7.96, \mathrm{df}=6, p<0.001)$; however, no difference $(F=0.65$, df $=1,14, p=0.43$ ) in FN was found in May.

\section{Discussion}

\section{Dietary analyses}

We contend that variation in deer diets was affected by the presence of cattle, which suggested that competition (winter) and facilitation (summer and fall) occurred between sympatric ungulate populations. Diets of deer in Pike County served as our control (ie absence of cattle), and as such, we assumed that deer in southern pine forests without cattle consume high percentages of browse and mast in October and low percentages of conifer and forb throughout the year. Thus, diets high in conifers among deer occupying habitats with a high stocking rate of cattle in winter would suggest that forage availability had declined, a prerequisite for competitive interactions.

Consumption of conifers and other evergreen browse in northern ecosystems occurs in winter when preferred forage is covered by snow and therefore is unavailable to deer (Coblentz 1970, Jenkins and Wright 1988, Osborn 1994). In southern forests, twigs of deciduous trees and shrubs receive limited use (ie $\leq 16 \%$ of diets) by deer in winter (Lay 1964, Cushwa et al. 1970, Harlow and Hooper 1971, Weckerly and Nelson 1990), possibly due to their high handling time relative to low energy and high fiber content (Illius and Gordon 1993). Increased conifer consumption by deer exposed to cattle grazing in winter could represent nonselective foraging (LaGory et al. 1985) relative to availability of loblolly pine. In February, conifer consumption was pronounced and tended to increase with cattle stocking rate (especially in February 1988). Conifers are low in digestibility (eg Pinus spp. digestibility in winter $=44.1 \%$, Blair et al. 1977) in all seasons, and the high percentage of conifer in the diet of deer in McCurtain County during winter $(\bar{x}=30 \%)$ suggested that higher quality forage may have been limited. Conversely, diets of deer from Pike County were lowest in conifer $(\bar{x}=6 \%)$ but highest in Caprifoliaceae (ie honeysuckle/coralberry), which averaged $35.2 \%$ of the diet in February 1987-1988 and was negatively correlated with consumption of conifers. 
Low Caprifoliaceae and high conifer consumption by deer on treatments with cattle in winter could have resulted from competitive interactions that could negatively affect the nutritional condition of deer. Caprifoliaceae rarely was observed in treatments with cattle; when observed it was found on fence rows that were unavailable to both species. Blair et al. (1984) found that Japanese honeysuckle had a digestibility of $64.7 \%$ in January. Furthermore, Segelquist et al. (1971) found that Japanese honeysuckle leaves were more digestible in winter than any native forage in Arkansas. In the hill counties of Ohio, diets of $29.9 \%$ of the deer sampled contained Japanese honeysuckle, which ranked second as a principal deer food in winter (Nixon et al. 1970). Furthermore, Jenks et al. (1994) noted that gastrointestinal tracts of deer collected from treatments with cattle had higher amounts of digestathan deer collected from Pike County possibly due to lowered fermentation rates associated with high conifer diets (Baker and Hobbs 1987).

Low amounts of forbs in diets of deer on the Pike County treatment may have resulted from successional patterns that occur in southern forests. In loblolly pine plantations, evenness of plant species (Pielou 1966) within the ground stratum decreases over the first 3 years post-clearing due to the increased dominance of broomsedge (Felix et al. 1983), a forage generally not preferred by deer. Thus, forb availability in areas dominated by broomsedge continues to decline temporally following clearing (Keever 1950, Pinder 1975). Where cattle occurred, the forb component of diets of deer was primarily composed of legumes and composites; cattle perhaps facilitated forb growth through the removal of the dominant broomsedge. Thill et al. (1987) found that winter rosettes of forbs and grasses were both more abundant and available where bunch grasses had been removed by cattle grazing. Cattle diets, especially under moderate stocking, contained a high proportion of Andropogon spp. indicating that at moderate stocking levels consumption of dominant grasses is necessary to facilitate forb growth (Thill et al. 1987).

Dietary overlap was low $(<67 \%)$ among deer across the 3 treatments and between deer and cattle in McCurtain and Howard counties $(<35 \%)$. Low dietary overlap among deer populations might have resulted from a shift in plant species composition due to the presence of cattle in McCurtain and Howard counties, which is consistent with the higher dietary overlap between McCurtain-Howard and Howard-Pike deer populations. Thill et al. (1987) noted that average dietary similarities of tame deer ranged from $52.6 \%$ to $61.8 \%$ across comparisons of grazed and ungrazed pastures in Louisiana; these levels of overlap were within the range of diet overlap estimates for our study.

Although dietary overlap between sympatric deer and cattle populations was low $(<35 \%)$, it was considerably higher than overlap between cattle and mule deer Odocoileus hemionus in Piceance Basin and Douglas Mountain, Colorado ( $\leq 4 \%$; Hubbard and Hansen 1976, Hansen et al. 1977). Currie et al. (1977) also found low dietary overlap between cattle and mule deer for the spring-fall grazing period in managed ponderosa pine Pinus ponderosa rangelands in Colorado. Overlap of mule deer and cattle diets in southern Colorado ranged from $12 \%$ to $38 \%$ (Hansen 
and Reid 1975). In our study, seasonal estimates of dietary overlap (ie spring = 21.1 , summer $=17.2$, autumn $=17.9$, winter $=32.9$ ) were lower than those determined for deer and cattle in central Louisiana in spring and autumn (spring $=25.8$, autumn $=26.0)$, higher in summer $(11.8)$, and similar for winter (30.7) (Thill and Martin 1989).

Dietary overlap between deer and cattle was highest in February in McCurtain County and approached the highest level in Howard County, which further suggested that winter was the season during which the potential for competition between deer and cattle was highest. Thill (1984) calculated a dietary overlap of $45.6 \%$ between tame deer and cattle on forested sites in Louisiana in winter; however, dietary overlap was $10.5 \%$ for deer and cattle on clear-cut pine-hardwood sites, which had a higher frequency of use by cattle than forested sites. McMahan (1964) considered competition to be heavy between deer and cattle, goats, and sheep in winter on the Edwards Plateau, Texas.

In our study, 3 factors that related consumption of forage categories to deer and cattle populations differed with respect to stocking regimes and explained $91.5 \%$ of the variation in dietary composition. Principal component 1 separated deer and cattle; cattle scored low on this axis due to their high dietary intake of grasses. Conversely, deer scored high on this axis due to high dietary browse and mast. Vangilder et al. (1982) found that separation (in multivariate space) occurred between forages that were high in rapidly fermented cell solubles and calcium (ie leaves and fruits of woody species) and those that have a high cellulose fraction (ie forbs, grasses and grains). Thus, major separation between deer and cattle along principal component 1 likely occurred because of physiological differences that exist between the 2 species; ie browser versus grazer (Hofmann and Stewart 1972, Hofmann 1988). Cattle select diets high in cellulose, which is retained in the rumen for a relatively long time (Hofmann 1988). Deer select diets high in rapidly fermentable cell solubles, which have a relatively short ruminal retention time (Short et al. 1974). During February, sympatric deer and cattle populations were more similar with respect to this axis than during other seasons. We suggest that this pattern resulted from competitive interactions that caused a shift toward forages that were unacceptable relative to cell soluble and cellulose content for both ungulate species (ie low grass for cattle and low browse/mast for deer).

Significant separation occurred among deer and cattle populations in February on principal component 2. Principal component 2 might be interpreted as a forage availability factor because differences in diets among deer populations that occurred relative to this factor were a result of conifer intake. Diets of deer in February tended to be more similar to diets of cattle when deer were exposed to heavy cattle stocking (ie McCurtain County). This information paralleled diet overlap indices for February (Table 1) and further suggested that the gratest level of dietary competition between deer and cattle occurred in winter.

Separation among deer populations also occurred on principal component 3 in February and August. Deer from Pike County scored high on this factor cue to 
low dietary forbs. Thus, this separation supported facilitation (Bell 1971, Gordon 1988) of deer consumption of forbs by cattle. Other researchers (Warren and Krysl 1983) have observed an increase in forb consumption by deer on rangelands grazed by cattle.

\section{Dietary quality}

Fecal nitrogen is composed of undigestible dietary nitrogen (including some secondary compounds and structural material), water soluble nitrogen, bacterial nitrogen, and endogenous nitrogen (Arman et al. 1975). Despite component variability, $\mathrm{FN}$ has been used to assess quality of diets of wild herbivores (Arman et al. 1975, Erasmus et al. 1978, Leslie and Starkey 1985, Wofford et al. 1985, Howery and Pfister 1990, Irwin et al. 1993) and to rank quality of wintering areas of white-tailed deer (Hodgman and Bowyer 1986). Coe (1983) found FN to be a good predictor of dietary nitrogen down to $5 \%$ crude protein. Hobbs (1987) elaborated on problems with FN as a predictor of dietary nitrogen; however, Leslie and Starkey (1987) argued that FN could be used under a variety of circumstances, which included seasonal intraspecific comparisons in similar habitats.

Although interspecies comparisons of FN between deer and cattle may be questionable because of differing digestive adaptations that can affect the mechanics of digestion (see Short 1963, 1964), FN was generally higher for deer than cattle in all seasons studied. Higher concentrations of FN in deer may occur due to high loss of fermentable material from the rumen to the intestines (Orskov et al. 1972 cited by Van Soest 1982: 47). For example, Jenks et al. (1994) found that deer collected from Pike County in winter had a higher proportion of digesta in intestines (when corrected for total mass of digesta in gastrointestinal tracts) than those deer collected from treatments with cattle. Conversely, Clemens and Maloiy (1983) found that percent dry matter in the small intestine decreased with increased consumption of grass when comparing 16 wild ruminant species. Cattle consumed a high proportion of grasses, which tend to be low in $\mathrm{N}$ content (Blair et al. 1977). Leslie and Starkey (1985) found that FN of elk was lower than deer in some seasons in old-growth forests.

Coefficients of determination $\left(r^{2}\right)$ for the relationship between dietary nitrogen and FN for deer have ranged from 0.57 (Robbins et al. 1975) to 0.95 (Leslie and Starkey 1985). Low $r^{2}$ values in some studies may have resulted from high concentrations of tannins (Mould and Robbins 1981), which bind proteins and reduce their digestibility (McLeod 1974, Reed 1986, Robbins et al. 1987a, b). Yet, forages that contain high concentrations of condensed tannins ( $>5 \%$ ) may not be preferred by wild ruminants (Cooper and Owen-Smith 1985, van Hoven and Furstenburg 1992) and concentrations of tannins in plants may peak during seasons when competition for forage is low (spring) (Happe et al. 1990). If secondary compounds had affected FN levels of deer, higher levels of FN would have been expected in deer feces from McCurtain and Howard counties because of an elevated intake of conifers. However, deer from Pike County had the highest 
level of FN in winter; diets of deer from Pike County were composed primarily of Caprifoliaceae. Fecal nitrogen of cattle from McCurtain County declined from October to February despite increased consumption of browse and conifer.

Levels of FN were lowest in winter and indicated that dietary quality also was lowest during this season. Because FN of deer from Pike County was higher than for treatments with cattle grazing, competition between deer and cattle for available forage may have caused deer to forage for dietary items that are lover in nitrogen (eg pine). Increased competition for forage between deer and cattle in February is supported by overlap indices and proximity of principal component scores for sympatric deer and cattle populations that were determined from dietary analyses. Feces from Pike County were lower in nitrogen concentration than those collected in McCurtain and Howard counties in August and October, which further suggested a facilitative effect of cattle grazing during these seasons.

Acknowledgements: We thank B. Dappert, L. Copeland, W. Stancill, R. B. Soper and S. Haggard for their help with fecal collections and laboratory analysis. Weyerhaeuser Company supplied stand naps to delineate treatments, and facilities for storage of fecal collections. W. D. Warde aided vith statistical aspects of the study. J. H. Shaw, J. R. Schuette, G. A. Jenks, D. E. Naugle, J. S. Gleason and C. S. DePerno made many helpful suggestions on this manuscript. Financial support for this research was provided by the Federal Aid in Wildlife Restoration Act under Project W-142-R of the Oklahoma Department of Wildlife Conservation and Oklahoma State University. Financial support also was provided by Weyerhaeuser Company and Oklahoma Cooperative Fish and Wildlife Research Unit (Oklahoma State University, Oklahoma Department of Wildlife Conservation, U.S. National Biological Service, and Wildlife Management Institute cooperating).

\section{References}

Alipayo D., Valdez R., Holechek J. L. and Cardenas. M. 1992. Evaluation of microhistological analysis for determining ruminant diet botanical composition. Journal of Range Management 45: 148-152.

Anthony R. G. and Smith N. S. 1974. Comparison of rumen and fecal analysis to describe deer food habits. Journal of Wildlife Management 38: 535-540.

Anthony R. G. and Smith N. S. 1977. Ecological relationships between mule deer and white-tailed deer in southeastern Arizona. Ecological Monographs 47: 255-277.

Arman P., Hopcraft D. and MacDonald I. 1975. Nutritional studies on east African herbivores. 2. Losses of nitrogen in the faeces. British Journal of Nutrition 33: 265-276.

Baker D. L. and N. T. Hobbs. 1987. Strategies of digestion: digestive efficiency and retention time of forage diets in montane ungulates. Canadian Journal of Zoology 65: 1978-1984.

Bell R. H. V. 1971. A grazing ecosystem in the Serengeti. Scientific American 224: 86-93.

Blair R. M., Short H. L., Burkart L. F., Harrell A. and Whelan J. B. 1984. Seasonality of nutrient quality and digestibility of three southern deer browse species. United States Department of Agriculture, Forest Service Research Paper SO-161: 1-13.

Blair R. M., Short H. L. and Epps E. A. Jr 1977. Seasonal nutrient yield and digestibility of deer forage from a young pine plantation. Journal of Wildlife Management 41: 667-676.

Clemens E. T. and Maloiy G. M. O. 1983. Digestive physiology of east African wild ruminants. Comparitive Biochemistry and Physiology 76A: 319-333.

Coblentz B. E. 1970. Food habits of George Reserve deer. Journal of Wildlife Management 34: 535-540.

Coe M. 1983. Nitrogen as an ecological factor. [In: Large herbivores and food quality. J. A. Lee, S. McNeill and I. H. Rorison, eds]. Blackwell Scientific Publications, Oxford: 345-368. 
Conover W. J. and Iman R. L. 1981. Rank transformations as a bridge between parametric and nonparametric statistics. American Statistician 35: 124-133.

Cooper S. M. and Owen-Smith N. 1985. Condensed tannins deter feeding by browsing ruminants in a south African savanna. Oecologia 67: 142-146.

Crawford H. S. 1984. Habitat management. [In: White-tailed deer ecology and management. L. K. Halls, ed]. Stackpole Books, Harrisburg, Pennsylvania: 629-646.

Currie P. O., Reichert D. W., Malechek J. C. and Wallmo O. C. 1977. Forage selection comparisons for mule deer and cattle under managed ponderosa pine. Journal of Range Management 30: 352-356.

Cushwa C. T., Downing R. L., Harlow R. F. and Urbston D. F. 1970. The importance of woody twig ends to deer in the southeast. United States Department of Agriculture, Forest Service Research Paper SE-67: 1-12.

Davitt B. B. and Nelson J. R. 1980. A method of preparing plant epidermal tissue for use in fecal analysis. Circular 0628, College of Agriculture Research Center, Washington State University, Pullman, Washington: 1-5.

Erasmus T., Penzhorn B. L. and Fairall N. 1978. Chemical composition of faeces as an index of veld quality. South African Journal of Wildlife Research 8: 19-24.

Felix A. C. III, Sharik T. L., McGinnes B. S., and Johnson W. C. 1983. Succession in loblolly pine plantations converted from second-growth forest in the central piedmont of Virginia. American Midland Naturalist 110: 365-380.

Foti T. L. 1974. Arkansas natural area plan. Arkansas Department of Planning, Little Rock, Arkansas: 11-24.

Fuller N. M. 1976. A nutrient analysis of plants potentially useful as deer forage on clearcut and selective-cut pine sites in southeastern Oklahoma. M Sc thesis, Oklahoma State University, Stillwater, Oklahoma: 1-65.

Gordon I. J. 1988. Facilitation of red deer grazing by cattle and its impact on red deer performance. Journal of Applied Ecology 25: 1-10.

Hansen R. M., Clark R. C. and Lawhorn W. 1977. Foods of wild horses, deer, and cattle in the Douglas Mountain Area, Colorado. Journal of Range Management 30: 116-118.

Hansen R. M. and Reid L. D. 1975. Diet overlap of deer, elk, and cattle in southern Colorado. Journal of Range Management 28: 43-47.

Happe P. J., Jenkins K. J., Starkey E. E. and Sharrow S. H. 1990. Nutritional quality and tannin astringency of browse in clear-cuts and old-growth forests. Journal of Wildlife Management 54: $557-566$.

Harlow R. F, and Hooper R. G. 1971. Forages eaten by deer in the southeast. Proceeding Annual Conference of the Southeastern Association of Game and Fish Commissioners 25: 18-46.

Harlow R. F., Whelan J. B., Crawford H. S. and Skeen J. E. 1975. Deer foods during years of oak mast abundance and scarcity. Journal of Wildlife Management 39: 330-336.

Hobbs N. T. 1987. Fecal indices to dietary quality: a critique. Journal of Wildlife Management 51: $317-320$.

Hodgman T. P. and Bowyer R. T. 1986. Fecal crude protein relative to browsing intensity by white-tailed deer on wintering areas in Maine. Acta Theriologica 31: 347-353.

Hofmann R. R. 1988. Anatomy of the gastro-intestinal tract. [In: The ruminant animal. D. C. Church, ed]. Prentice Hall, Englewood Cliffs, New Jersey: 2-43.

Hofmann R. R. and Stewart D. R. M. 1972. Grazer vs, browser; a classification based on the stomach structure and feeding habits of east African ruminants. Mammalia 36: 226-240.

Holechek J. L. and Valdez R. 1985. Magnification and shrub stemmy material influences on fecal analysis accuracy. Journal of Range Management 38: 350-352.

Howery L. D. and Pfister J. A. 1990. Dietary and fecal concentrations of nitrogen and phosphorus in penned white-tailed deer does. Journal of Wildlife Management 54: 383-389.

Hubbard R. E. and Hansen R. M. 1976. Diets of wild horses, cattle, and mule deer in the Piceance Basin, Colorado. Journal of Range Managment 29: 389-392. 
Illius A. W. and Gordon I. J. 1993. Diet selection in mammalian herbivores: constraints and tactics. [In: Diet selection. R. N. Hughs, ed]. Blackwell Scientific Publications, London: 157-181.

Irwin L. L., Cook J. G., McWhirten D. E., Smith S. G. and Arnett E. B. 1993. Assessing winter dietary quality in bighorn sheep via fecal nitrogen. Journal of Wildlife Management 57: 413-427.

James R. W. 1982. Oklahoma soil survey. Weyerhaeuser Company, Tacoma, Washington: 1-64.

Jenkins D. V. and Steinbrenner E. C. 1981. Soil survey of the southwestern Arkansas region. Weyerhaeuser Company, Tacoma, Washington: 1-35.

Jenkins K. J. and Wright R. G. 1988. Resource partitioning and competition among cervids in the northern Rocky Mountains. Journal of Applied Ecology 25: 11-24.

Jenks J. A. 1991. Effect of cattle stocking rate on the nutritional ecology of white-tailed deer in managed forests of southeastern Oklahoma and southwestern Arkansas. Ph D thesis, Oklahoma State University, Stillwater, Oklahoma: 1-131.

Jenks J. A., Leslie D. M. Jr, Lochmiller R. L. and Melchiors M. A. 1994. Variation in gastrointestinal characteristics of male and female white-tailed deer: implications for resource partitioning. Journal of Mammalogy 75: 1045-1053.

Jenks J. A., Leslie D. M. Jr, Lochmiller R. L., Melchiors M. A. and Warde W. D. 1989. Effect of compositing samples on analysis of fecal nitrogen. Journal of Wildlife Management 53: 213-215.

Jenks J. A., Soper R. B., Lochmiller R. L. and Leslie D. M. Jr 1990. Effect of exposure on nitrogen and fiber characteristics of white-tailed deer feces. Journal of Wildlife Management 54: 389-391.

Johnson R. A. and Wichern D. W. 1988. Applied multivariate statistical analysis. Prentice Hall, Englewood Cliffs, NJ: 1-607.

Keever C. 1950. Causes of succession on old fields of the Piedmont, North Carolina. Ecological Monographs 20: 229-250.

Korschgen L. J. 1962. Foods of Missouri deer, with some management implications. Journal of Wildlife Management 26: 164-172.

LaGory M. K., LaGory K. E. and Taylor D. H. 1985. Winter browse availability and use by white-tailed deer in southeastern Indiana. Journal of Wildlife Management 49: 120-124.

Lay D. W. 1964. The importance of variety to southern deer. Proceedings Annual Conference of the Southeastern Association of Game and Fish Commissioners 18: 57-62.

Leslie D. M. Jr and Starkey E. E. 1985. Fecal indices to dietary quality of cervids in old-growth forests. Journal of Wildlife Management 49: 142-146.

Leslie D. M. Jr and Starkey E. E. 1987. Fecal indices to dietary quality: a reply. Journal of Wildlife Management 51: 321-325.

Leslie D. M. Jr, Starkey E. E. and Vavra M. 1984. Elk and deer diets in old-growth forests in western Washington. Journal of Wildlife Management 48: 762-775.

McLeod M. N. 1974. Plant tannins-their role in forage quality. Nutrition Abstracts Review 44: 803-815.

McMahan C. A. 1964. Comparative food habits of deer and three classes of livestock. Journal of Wildlife Management 28: 798-808.

Mould E. D. and Robbins C. T. 1981. Nitrogen metabolism in elk. Journal of Wildlife Mangement 45: 323-334.

Nelson J. S. 1981. White-tailed deer and cattle interactions in southeastern Oklahoma. M Sc thesis, Oklahoma State University, Stillwater, Oklahoma: 1-65.

Nixon C. M., McClain M. W. and Russell K. R. 1970. Deer food habits and range characteristics in Ohio. Journal of Wildlife Management 34: 870-886.

Osborn R. G. 1994. Winter diet and nutritional condition of white-tailed deer in the northern Black Hills, South Dakota. M Sc thesis, South Dakota State University, Brookings, South Dakota: 1-164.

Pielou E. C. 1966. The measurement of diversity in different types of biological collections. Journal of Theoretical Biology 13: 131-144. 
Pinder J. E. III. 1975. Effects of species removal on an old-field plant community, Ecology 56: $747-751$.

Reed J. D. 1986. Relationships among soluble phenolics, insoluble proanthocyanidins and fiber in east African browse species. Journal of Range Management 39: 5-7.

Robbins C. T., Hanley T. A., Hagerman A. E., Hjeljord O., Baker D. L., Schwartz C. C. and Mautz W. W. 1987a. Role of tannins in defending plants against ruminants: reduction of protein availability. Ecology 68: 98-107.

Robbins C. T., Mole S., Hagerman A. E. and Hanley T. A. 1987b. Role of tannins in defending plants against ruminants: reduction in dry matter digestion. Ecology 68: 1606-1615.

Robbins C. T., Van Soest P. J., Mautz W. W. and Moen A. N. 1975. Feed analyses and digestion with reference to white-tailed deer. Journal of Wildlife Management 39: 67-79.

Segelquist C. A., Rogers M. and Ward F. D. 1971. Quantity and quality of Japanese honeysuckle on Arkansas food plots. Proceedings Annual Conference of the Southeastern Association of Game and Fish Commissioners 25: 47-53

Short H. L. 1963. Rumen fermentations and energy relationships in white-tailed deer. Journal of Wildlife Management 27: 184-195.

Short H. L. 1964. Postnatal stomach development of white-tailed deer. Journal of Wildlife Management 28: $445-448$.

Short H. L., Blair R. M. and Segelquist C. A. 1974. Fiber composition and forage digestibility by small ruminants. Journal of Wildlife Management 38: 197-209.

Sinclair A. R. E, 1979. Dynamics of the Serengeti ecosystem. [In: Serengeti, dynamics of an ecosystem. A. R. E. Sinclair and M. Norton-Griffiths, eds]. The University of Chicago Press, London: 1-30.

Sokal R. R. and Rohlf F. J. 1981. Biometry. W. H. Freeman and Company, New York: 1-859.

Sparks D. R. and Malechek J. C. 1968. Estimating percentage dry weight in diets using a microscopic technique. Journal of Range Management 21: 264-265.

Stewart D. R. 1967. Analysis of plant epidermis in faeces: a technique for studying the food preferences of grazing herbivores. Journal of Applied Ecology 4: 83-111.

Thill R. E. 1984. Deer and cattle diets on Louisiana pine-hardwood sites. Journal of Wildlife Management 48: 788-798.

Thill R. E. and Martin A. Jr 1989. Deer and cattle diets on heavily grazed pine-bluestem range. Journal of Wildlife Management 53: 540-548.

Thill R. E., Martin A. Jr, Morris H. F. Jr and McCune E. D. 1987. Grazing and burning impacts on deer diets on Louisiana pine-bluestem range. Journal of Wildlife Management 51: 873-880.

Vangilder L. D., Torgerson O, and Porath W. R. 1982. Factors influencing diet selection by white-tailed deer. Journal of Wildlife Management 46: 711-718.

Van Hoven W. and Furstenburg D. 1992. The use of purified condensed tannin as a reference in determining its influence on rumen fermentation. Comparative Biochemistry and Physiology 101A: 381-385

Van Soest P. J. 1982. Nutritional ecology of the ruminant. Cornell University Press, Ithaca, NY: $1-373$.

Waid D. D., Warren R. J. and Rollins D. 1984. Seasonal deer diets in central Texas and their response to brush control. Southwestern Naturalist 29: 301-307.

Warren R. J. and Krysl L. J. 1983. White-tailed deer food habits and nutritional status as affected by grazing and deer-harvest management. Journal of Range Management 36: 104-109.

Weckerly F. W. and Nelson J. P. Jr 1990. Age and sex differences of white-tailed deer diet composition, quality, and calcium. Journal of Wildlife Management 54: 532-538.

Welch J. G. and A. P. Hooper. 1988. Ingestion of feed and water. IIn: The ruminant animal. D. C. Church, ed]. Prentice Hall, Englewood Cliffs, New Jersey: 108-116.

Whysong G. L. and Miller W. H. 1987. An evaluation of random and systematic plot placement for estimating frequency. Journal of Range Management 40: 475-479. 
Williams S. (ed) 1984. Official methods of analysis of the Association of Official Analytical Chemists. Fourteenth Edition of the Association of Official Analytical Chemists, Washington, D.C.: 1-1141. Wofford H., Holechek J. L., Gaylean M. L., Wallace J. D. and Cardenas M. 1985. Evaluation of fecal indices to predict cattle diet quality. Journal of Range Management 38: 450-454.

Received 9 August 1995, accepted 2 March 1996. 